\title{
PELAKSANAAN AKAD PEMBIAYAAN MURABAHAH PADA BTPN SYARIAH PALANGKA RAYA
}

\author{
Endah Ayu Lestari ${ }^{1)}, *$ Rinto Alexandro ${ }^{2)}$ \\ 1)Prodi Pendidikan Ekonomi Universitas Palangka Raya, Indonesia \\ 2)Prodi Pendidikan Ekonomi Universitas Palangka Raya, Indonesia \\ *Email Korespondensi : rinto.alexandro@fkip.upr.ac.id
}

\begin{abstract}
Abstrak
Bank syariah merupakan bank yang kegiatannya mengacu pada hukum Islam, dan dalam kegiatannya tidak membebankan bunga maupun tidak membayar bunga kepada nasabah. Imbalan yang diterima oleh bank syariah maupun yang dibayarkan kepada nasabah tergantung dari akad dan perjanjian antara nasabah dan bank. Perjanjian (akad) yang terdapat di perbankan syariah harus tunduk pada syarat dan rukun akad sebagaimana diatur dalam syariah Islam. Bank BTPN Syariah Unit Bisnis Wisma Palangka Raya ini menggunakan satu produk pembiayaan yaitu pembiayaan Murabahah. Tujuan Penelitian adalah Untuk mengetahui dan mendeskripsikan pelaksanaan mengenai akad murabahah dalam produk pembiayaan pada Bank BTPN Syariah Palangka Raya dan Untuk mengetahui dan mendeskripsikan hambatan-hambatan pelaksanaan akad murabahah pada Bank BTPN Syariah Palangka Raya. Pendekatan penelitian yang digunakan ini adalah pendekatan kualitatif. Hasil penelitian adalah Bank syariah di Indonesia terutama bank BTPN Syariah Palangka Raya pada umumnya dalam memberikan pembiayaan murabahah, menetapkan syarat-syarat yang dibutuhkan dan prosedur yang harus ditempuh oleh musytari yang hampir sama dengan syarat dan prosedur kredit sebagaimana lazimnya yang ditetapkan oleh bank konvensional.
\end{abstract}

Kata Kunci: Akad Pembiayaan Murabahah; BTPN Syariah; Hukum Islam

\begin{abstract}
Islamic banks are banks whose activities refer to Islamic law, and in their activities do not charge interest or pay interest to customers. Rewards received by Islamic banks and paid to customers depend on the contract and agreement between the customer and the bank. The agreement (contract) contained in Islamic banking must comply with the terms and conditions of the contract as stipulated in Islamic sharia. Bank BTPN Syariah Wisma Palangka Raya Business Unit uses one financing product, namely Murabahah financing. The research objectives were to find out and describe the implementation of the murabahah contract in the financing product at Bank BTPN Syariah Palangka Raya and to find out and describe the obstacles to implementing the murabahah contract at Bank BTPN Syariah Palangka Raya. The research approach used is a qualitative approach. The results of the study show that Islamic banks in Indonesia, especially the BTPN Syariah Palangka Raya bank, in general, in providing murabahah financing, determine the
\end{abstract}


conditions needed and the procedures that must be followed by musytari which are almost the same as the usual credit terms and procedures set by conventional banks.

Key Words: Murabahah Financing Agreement, BTPN Syariah, Islamic Law

\section{PENDAHULUAN}

Bank merupakan lembaga keuangan yang mempunyai peranan sangat strategis dalam mengembangkan pembangunan nasional. Kegiatan utama dari perbankan adalah menyerap dan meyalurkan dana ke masyarakat. Dunia perbankan mengenal dua sistem, yaitu sistem ekonomi konvensional dan sistem ekonomi syariah. Menurut UndangUndang Perbankan Nomor 10 Tahun 1998 yang dimaksud dengan bank adalah "badan usaha yang menghimpun dana dari masyarakat dalam bentuk simpanan dan menyalurkannya ke masyarakat dalam bentuk kredit dan/atau bentuk lainnya dalam rangka meningkatkan taraf hidup rakyat bank". Bank syariah di Indonesia lahir sejak 1992. Bank syariah pertama di Indonesia adalah Bank Muamalat Indonesia dan Bank Syariah Mandiri ialah bank syariah kedua di Indonesia.

Bank syariah memiliki sistem operasional yang berbeda dengan bank konvensional. Bank syariah memberikan layanan bebas bunga kepada para nasabahnya. Dalam sistem operasional bank syariah, pembayaran dan penarikan bunga dilarang dalam semua bentuk transaksi bank syariah tidak mengenal sistem bunga, baik bunga yang diperoleh dari nasabah yang meminjam uang atau bunga yang dibayar kepada penyimpan dana di bank syariah. Setiap pelaksanaan komponen pengelolaan keuangan harus didasari adanya akuntabilitas atau pertanggungjawaban (Hanum, 2018). Begitupula keuangan di Bank Syariah.

Bank juga memiliki peranan penting dalam peningkatan kesejahteraan masyarakat. Peningkatan kesejahteraan masyarakat merupakan kerja keras dalam mencari ide dan gagasan dalam memberdayakan potensi yang dimiliki daerah. Hal ini sebagai bentuk pengembangan ekonomi kreatif masyarakat. (Dudi \& Bramantyo, 2019). Disamping itu, keberadaan Bank Syariah tidak terlepas pula dari kondisi kehidupan sosial ekonomi masyarakat dan juga memperhatikan aspirasi dan mind-set masyarakat (Mujiarto et al., 2019) 


\section{TINJAUAN PUSTAKA}

Menurut Undang-Undang Perbankan Syariah No.21 Tahun 2008 "Perbankan syariah adalah segala sesuatu yang tentang bank syariah mencakup kelembagaan, kegiatan usaha, serta cara dan proses dalam melaksanakan kegiatan usahanya”. Bank syariah adalah bank yang menjalankan kegiatan usahanya berdasarkan prinsip syariah dan menurut jenisnya terdiri dari atas Bank Umum Syariah (BUS), Unit Usaha Syariah (UUS), dan Bank Pembiayaan Rakyat Syariah (BPRS). Bank syariah memiliki fungsi menghimpun dana dari masyarakat dalam bentuk titipan dan investasi dari pihak pemilik dana. Fungsi lainnya ialah menyalurkan dana kepada pihak lain yang membutuhkan dana dalam bentuk jual beli maupun kerja sama usaha.

Bank syariah merupakan bank yang kegiatannya mengacu pada hukum Islam, dan dalam kegiatannya tidak membebankan bunga maupun tidak membayar bunga kepada nasabah. Imbalan yang diterima oleh bank syariah maupun yang dibayarkan kepada nasabah tergantung dari akad dan perjanjian antara nasabah dan bank. Perjanjian (akad) yang terdapat di perbankan syariah harus tunduk pada syarat dan rukun akad sebagaimana diatur dalam syariah islam.

Menurut Ismail (2011:135), Salah satu pembiayaan yang dikenal di bank syariah adalah pembiayaan yang menggunakan akad jual beli. Jual beli merupakan transaksi yang dilakukan oleh pihak penjual dan pembeli atas barang dan jasa yang menjadi objek transaksi jual beli. Akad jual beli dapat diaplikasikan dalam pembiayaan yang diberikan oleh bank syariah. Pembiayaan yang menggunakan akad jual beli dikembangkan di bank syariah dalam tiga jenis pembiayaan, yaitu pembiayaan murabahah, istishna, dan salam,

Berdasarkan observasi di BTPN syariah Palangka Raya, proses pembiayaan jual beli menggunakan akad murabahah. Menurut Ismail (2011:138) mengatakan: murabahah adalah akad jual beli atas barang tertentu, dimana penjual menyebutkan harga pembelian barang kepada pembeli kemudian menjual kepada pihak pembeli dengan mensyaratkan keuntungan yang diharapkan sesuai jumlah tertentu. Dalam akad murabahah, penjual menjual barangnya dengan meminta kelebihan atas harga beli dengan harga jual.

Keberadaan perbankan syariah di tengah-tengah aktivitas perekonomian sebagai alternatif dari perbankan konvensional merupakan suatu hal yang cukup positif. 
Masyarakat muslim telah mendapatkan solusi atas permasalahan yang terkait dengan fatwa MUI tentang pengharaman bunga bank. Pembiayaan murabahah sampai saat ini masih merupakan pembiayaan yang dominan dalam perbankan syariah. Hal ini dikarenakan murabahah cenderung memiiki resiko yang lebih kecil dan lebih aman bagi para pemegang saham (stakeholder). Penentuan harga merupakan salah satu aspek dalam kegiatan pemasaran. Harga menjadi sangat penting untuk diperhatikan, mengingat harga sangat menentukan laku tidaknya produk dan jasa perbankan. Salah dalam menentukan harga akan berakibat fatal terhadap produk yang ditawarkan.

Menurut Karim (2006:97) dalam bukunya Bank Islam Analisis Fiqih dan Keuangan, Produk-produk yang ditawarkan oleh perbankan syariah sebagai kegiatan finansial pada bank syariah termasuk bank btpn syariah pada dasarnya dapat dibagi menjadi 3 bagian besar, yaitu Produk Penghimpun Dana (funding); 2) Produk Penyaluran Dana (financing); 3) Produk Jasa (service).

Salah satu lembaga yang bergerak dibidang bank syariah adalah bank BTPN Syariah yang selanjutnya dalam penelitian ini disebut Bank BTPN Syariah Unit Bisnis Wisma Palangka Raya. Bank BTPN Syariah Unit Bisnis Wisma Palangka Raya ini menggunakan satu produk pembiayaan yaitu pembiayaan Murabahah. Pembiayaan Murabahah dalam konteks Bank BTPN Syariah Unit Bisnis Wisma Palangka Raya ini merupakan produk pembiayaan yang bertujuan untuk mengkomodir kebutuhan masyarakat menengah kebawah dalam pemberian pembiayaan modal usaha mikro yaitu media Akad Murabahah.

Pengertian produk Murabahah dalam keputusan tersebut disebutkan bahwa pembiayaan Murabahah adalah pembiayaan dengan sistem jual beli dimana Bank BTPN Syariah dapat membantu nasabahnya dengan membiayai pembelian barang yang dibutuhkan untuk modal usaha. Penggunaan Akad Murabahah tersebut dalam perikatan pembiayaan modal usaha di Bank BTPN Syariah Unit Bisnis Wisma Palangka Raya menetapkan margin 30\%, dengan penetapan margin keuntungan murabahah yang tinggi, secara tidak langsung akan dapat menyebabkan inflasi yang lebih besar dari pada yang disebabkan oleh suku bunga. Oleh karena itu, perlu dicari format atau formula yang tepat, agar nilai penjualan dengan murabahah tidak mengacu pada sikap mengantisipasi 
kenaikan suku bunga selama masa pembayaran cicilan, karena mengkaitkan margin keuntungan murabahah dengan perbankan konvensional, baik di atasnya maupun dibawahnya, tetaplah bukan cara yang baik. Banyak kritikan dilontarkan pada bank syariah dalam masalah penetapan margin keuntungan. Hal ini dikarenakan produk pembiayaan murabahah merupakan produk yang mirip dengan produk pembiayaan kredit berbunga flat pada bank konvensional.

Produk pembiayaan murabahah di Bank BTPN Syariah Unit Bisnis Wisma Palangka Raya untuk mendapatkan keuntungan dari pihak nasabah adalah dengan menentukan margin keuntungan. Dalam praktiknya, perbankan syariah dalam menentukan kebijakan harga jual yang diinginkan tidak terlepas dari rujukan (benchmark) kepada suku bunga konvensional, tingkat pesaing (competitor), dan lain-lain. Sehingga masih terdapat kritikan-kritikan terhadap beberapa praktik yang dilakukan perbankan syariah terutama pada harga jual-beli yang dianggap masih sama dengan kredit pada bank konvensional. Karim (2006:152) mengatakan: Hal ini didasarkan pada kenyaataan bahwa proses penentuan jual-beli pada bank syariah menggunakan metode pembebanan bunga yang mengacu pada SBI (Suku Bunga Bank Indonesia) dan prinsip cost of fund yang merupakan pikiran utama dalam perbankan konvensional.

Akad murabahah adalah salah satu akad yang sering dimunculkan dalam perbankan syariah untuk kegiatan perusahaan dalam pembiayaan syariah. Akad ini sering ditawarkan oleh pihak bank kepada nasabah dan sering juga masyarakat menggunakannya dengan alasan keunggulan dari akad murabahah itu sendiri diantaranya jual beli dalam perbankan syariah adalah bank dapat memotong mata rantai jual beli, bank dapat pula menguasai mata rantai dalam jual beli (produsen, distributor, agen sampai toko sekalipun). Dalam mata rantai tersebut, minimal bank syariah bisa menjalin kerjasama dengan agen.

Menurut fatwa DSN-MUI (Dewan Syariah Nasional-Majelis Ulama Indonesia) dijelaskan bahwa yang dimaksud dengan murabahah adalah menjual dengan suatu barang dan menegaskan harga belinya kepada pembeli dan pembeli membayarnya dengan harga yang lebih sebagai laba.

Sedangkan dalam PSAK (Pernyataan Standar Akuntansi Keuangan) 59 tentang akuntansi perbankan syariah paragraf 52 dijelaskan bahwa murabahah adalah akad jual 
beli barang dengan menyatakan harga perolehan dan keuntungan dan margin yang disepakati oleh penjual dan pembeli. Akad murabahah merupakan akad jual beli barang pada harga pokok dengan tambahan keuntungan yang diketahui serta disepakati, akibat transaksi jual beli murabahah menyebabkan timbulnya piutang murabahah. Karena adanya penangguhan pembayaran ini menimbulkan kesan bahwa pembiayaan murabahah tidak berbeda dengan pemberian kredit berbunga oleh bank konvensional. Di dalam debt financing (pembiayaan hutang) bank konvensional ada beberapa unsur seperti adanya pre fixed interest (bunga) yang ditetapkan di awal peminjaman, bunga tersebut muncul akibat dari penundaan pembayaran dan wujudnya spekulasi. Kalau dalam konvensional ada prefixed interest, maka di dalam murabahah ada pre-fixed profit (suatu penetapan tambahan), dan penambahan itu juga disebabkan karena adanya unsur penundaan pembayaran. Unsur spekulasi terhadap perubahan base landing rate (suku bunga) telah dihilangkan dengan memakai fixed rate (nilai mark up yang tetap).

\section{METODE PENELITIAN}

Pendekatan penelitian yang digunakan ini adalah pendekatan kualitatif. pendekatan ini dilakukan pada semua objek penelitian agar proses pencarian data dapat berjalan dengan mudah dan sesuai rencana. Teknik pengumpulan data dilakukan secara induktif (penarikan kesimpulan berdasarkan keadaan-keadaan yang khusus untuk diperlakukan secara umum).

Dalam penelitian ini penulis menggunakan jenis penelitian deskriptif. Metode deskriptif ini merupakan metode yang diawali dengan adanya masalah, menentukan jenis informasi yang diperlukan, menentukan prosedur pengumpulan data melalui observasi atau pengamatan bertujuan untuk mengetahui sifat antara dua variabel dengan cara mengolah data dan menarik kesimpulan penelitian. Lokasi dari penelitian ini yang akan menjadi objek penelitian adalah Bank BTPN Syariah cabang Palangka Raya merupakan Kantor Cabang (KC) dari Bank BTPN Syariah Indonesia. Data-data diamati dan menjadi fokus pengamatan disini adalah proses akad murabahah dalam produk pembiayaan pada Bank BTPN syariah Palangka Raya dan Hambatan-hambatan akad murabahah pada Bank BTPN Syariah Palangka Raya. Analisa data yang meneliti menggunakan untuk 
menganalisa data-data yang didapat data-data tertentu dari penelitian ini adalah menggunakan analisis kualitatif.

\section{HASIL DAN PEMBAHASAN}

\section{Pelaksanaan Akad Murabahah dalam Produk Pembiayaan pada Bank BTPN Syariah Palangka Raya.}

Menurut Antonio (2001:37) "Pembiayaan yaitu pemberian fasilitas penyediaan dana untuk memenuhi kebutuhan pihak-pihak yang merupakan defisit unit”. Dasar hukum pembiayaan pada Bank Syariah adalah undang-undang Perbankan Syariah, pada pasal 19 Ayat (1) maka diketahui bahwa kegiatan usaha Bank Umum Syariah dalam hal pembiayaan diantaranya adalah menyalurkan Pembiayaan bagi hasil berdasarkan Akad Mudharabah, Akad Musyarakah.

Dan juga penelitian yang dilakukan oleh Fikri (2016) mengatakan bahwa pelaksanaan akad Murabahah pada Bank Muamalat cabang Bandar Lampung untuk membeli obyek atau barang yang telah disepakati dalam akad. Nasabah berkewajiban membayar sisa harga jual yang belum dilunasi, sehingga pelaksanaan akad murabahah pada Bank Muamalat Cabang Bandar Lampung tidak bertentangan atau melanggar regulasi/ketentuan yang ada, baik ketentuan umum Undang-Undang Perbankan Syariah Nomor 21 Tahun 2008 maupun ketentuan yang dikeluarkan oleh Dewan Syariah Nasional Majelis Ulama Indonesia Nomor 04/DSN-MUI/IV/2000 tentang murabahah dan Peraturan Bank Indonesia Nomor 7/46/PBI/2005 tentang akad penghimpun dan penyaluran dana bagi Bank yang Melaksanakan Kegiatan Usaha Berdasarkan Prinsip Syariah.

Produk murabahah ini merupakan produk pembiayaan di mana pihak bank dapat sebagai mediasi antara pihak yang berkepentingan, yaitu nasabah dan developer atau pemasok, maksudnya dalam hal ini adalah apabila nasabah menginginkan memiliki atau membeli sesuatu barang dari developer sementara nasabah belum memiliki dana yang cukup untuk dapat membelinya, maka bank dalam hal ini memberikan bantuan berupa pembiayaan dengan cara membeli barang yang diinginkan oleh nasabah terlebih dahulu dari developer, kemudian pihak bank menjual kembali barang tersebut kepada nasabah 
dengan harga sesuai dengan pembelian pihak bank dari pihak developer dengan metode angsuran dan ditambah keuntungan bagi pihak bank yang telah disepakati antara pihak bank dan pihak nasabah sebelum transaksi jual-beli dilakukan.

Keunggulan pembiayaan dari produk murabahah adalah bahwa nasabah dapat membeli sesuatu barang sesuai dengan keinginan, dan kemampuan ekonominya, di samping itu pembiayaannya dilakukan dengan angsuran sehingga tidak memberatkan pihak nasabah itu sendiri adapun keunggulan yang lain adalah bahwa dalam produk murabahah tidak mengenal riba atau sistem bunga tetapi dalam hal ini adanya keterbukaan antara pihak bank dan nasabah bahwa bank sebelumnya memberikan informasi atas barang yang akan dibeli sesuai dengan keinginan nasabah dan harga yang telah ditentukan oleh developer telah diketahui oleh pihak nasabah, kemudian pihak bank menjual kembali kepada nasabah sesuai dengan harga pembelian dari pihak developer, dan ditambah keuntungan bagi pihak bank. Tambahan keuntungan bagi pihak bank ini, diperjanjikan diawal transaksi yang didasarkan atas kesepakatan bersama antara pihak bank dengan nasabah, jadi dalam hal ini tidak terjadi unsur saling mendzalimi.

Transaksi jual-beli pada umumnya dapat dijelaskan mengenai unsur jaminan (dhomman). Kedudukan dhomman dalam transaksi jual-beli secarateori bahwa dhomman hanya sebatas pada penjual bahwa penjualmenjamin barang yang dijual tidak adanya cacat tersembunyi.

Menurut mayoritas (jumhur) ahli-ahli hukum Islam, rukun yang membentuk akad murabahah ada lima yaitu : Adanya penjual ( $b a^{\prime} i$ ); adanya pembeli (musytari); objek atau barang (mabi') yang diperjual-belikan; Harga (tsaman) nilai jual barang berdasarkan mata uang; ijab kabul (sighat) atau formula akad, suatu pernyataan kehendak oleh masingmasing pihak. Pembiayaan murabahah memungkinkan adanya dhomman (jaminan), karena sifat dari pembiayaan murabahah merupakan jual-beli yang pembayarannya tidak dilakukan secara tunai, maka tanggungan pembayaran tersebut merupakan hutang yang harus dibayar oleh musytari. Bank syariah (ba’i) memberlakukan prinsip kehatihatian dengan mengenakan dhomman pada nasabah.

Keberadaan agunan atau dhomman pada bank syariah sekilas memang menjadi permasalahan bagi pihak yang ingin mengajukan pembiayaan, apalagi jika tidak 
mempunyai dhomman yang dapat dijaminkan untuk memperoleh pembiayaan dari bank syariah. Hal ini menjadi masalah yang berat karena pihak bank syariah akan menyeleksi nasabah dari aspek kelayakan untuk memperoleh pembiayaan baik dari sisi personal ataupun dari sisi finansial, dari sisi personal, biasanya pihak bank syariah akan melihat terlebih dahulu sosok orangnya, apakah orang tersebut mempunyai itikad baik dan layak untuk mendapat pembiayaan atau tidak, sedangkan dari sisi finansial biasanya didasarkan pada kemampuan dalam melakukan pembayaran.

Sebagai salah satu contoh adalah pada pembiayaan murabahah di BTPN syariah Palangka Raya, terdapat unsur dhomman yang memiliki kedudukan penting dimana dhomman merupakan suatu keharusan, padahal kedudukan dhomman secara teorinya ialah bahwa tidak diperlukannya unsur dhomman pada setiap produk-produk bank syariah karena ketentuan awalbank syariah tidak mengenal dhomman melainkan menggunakan sistem kepercayaan, dan apabila dilihat dari regulasi yang terdapat pada fatwa DSN No. 04/DSN-MUI/IV/2000 terdapat point yang menjelaskan dhomman dalam pembiayaan murabahah dibolehkan, agar nasabah serius dengan pesanannya, jadi bahwa dhomman bisa dijelaskan diperbolehkan untuk mengetahui keseriusan nasabah (musytari) dengan pesanannya terhadap bank (ba'i), tetapi dalam praktik perbankan syariah, adanya dhomman merupakan suatu keharusan dari pihak nasabah, makaimplementasinya di perbankan syariah, kedudukan dhomman merupakan syarat wajib pihak bank pada nasabah, apabila akan melakukan suatu pembiayaan.

Bank syariah di Indonesia terutama bank BTPN syariah Palangka Raya pada umumnya dalam memberikan pembiayaan murabahah, menetapkan syarat-syarat yang dibutuhkan dan prosedur yang harus ditempuh oleh musytari yang hampir sama dengan syarat dan prosedur kredit sebagaimana lazimnya yang ditetapkan oleh bank konvensional. Syarat dan ketentuan umum pembiayaan murabahah, yaitu: Umum, tidak hanya diperuntukkan untuk kaum muslim saja; Harus cakap hukum, sesuai dengan KUH Perdata; Memenuhi 5 C yaitu: Character (watak); Collateral (jaminan); Capital (modal); Condition of economy (prospek usaha); Capability (kemampuan).

Memenuhi ketentuan Bank Indonesia dan pemerintah, sesuai yang diatur dalam Undang-Undang No. 10 Tahun 1998 tentang Perubahan Undang-Undang No. 7 Tahun 
1992 tentang Perbankan; Jaminan (dhomman), biasanya cukup dengan barang yang dijadikan obyek perjanjian namun karena besarnya pembiayaan lebih besar dari harga pokok barang (karena ada mark up) maka pihak bank mengenakan uang muka senilai kelebihan jumlah pembiayaan yang tidak tertutup oleh harga pokok barang.

\section{Hambatan-hambatan pada pelaksanaan pembiayaan Akad Murabahah pada Bank BTPN Palangka Raya.}

Pada umumnya bank syariah selaku ba'i mempunyai kendala teknis terhadap pengadaan barang karena bank syariah tidak mempunyai persediaan barang dan spesialisasi barang yang dijual sementara musytari membutuhkan barang yang beragam jenisnya. Praktik yang sering terjadi pihak bank syariah tidak murni sebagai penjual barang seperti pada industri perdagangan yang menjual barang secara langsung kepada pembeli, karena pada umumnya bank (ba'i) tidak mempunyai persediaan barang, bank juga bukan sebagai agen investasi karena tidak menawarkan barang yang menjadi obyek jual-beli.

Sebagai gambaran tentang praktik pembiayaan murabahah di bank syariah pada umumnya di Indonesia, Penulis akan memaparkan beberapa contoh bentuk pembiayaan murabahah yang biasa dilakukan oleh bank BTPN syariah Palangka Raya, yaitu sebagai berikut:

a. Contoh akad pembiayaan murabahah untuk perbaikan atau renovasi rumah, yaitu sebagai berikut: musytari yang akan mengajukan pembiayaan renovasi sebuah rumah ketika telah disetujui maka pihak bank (ba'i) akan memberikan dana yang kemudian dengan sebuah surat kuasa dari ba'i, musytari diberi amanah untuk membeli bahanbahan bangunan yang dibutuhkannya, dengan syarat selama 30 (tiga puluh) hari musytari tersebut sudah membeli bahan-bahan bangunan yang ditunjukkan dengan bukti pembelian berupa nota ataupun faktur. Hal ini terjadi karena menurut pihak bank selaku ba'i akan sulit sekali apabilaba'i yang melakukan pembelian sendiri atas barang-barang yang diperlukan dalam renovasi rumah tersebut;

b. Contoh akad pembiayaan murabahah untuk pembelian sebuah mobil, yaitu sebagai berikut: berbeda dengan pembiayaan murabahah untuk renovasi rumah, untuk pembelian mobil karena obyeknya (mobil) jelas, pasti dan diketahui secara jelas siapa 
pemiliknya (supplier) maka pihak ba'i akan secara langsung menghadirkan supplier (penjual mobil) tersebut dalam akad yang akan dilaksanakan antara $b a^{\prime} i$ dan musytari, artinya pihak ba'i secara langsung akan memberikan uang kepada supplier (pemilik mobil) sebagai pemilik mobil tersebut yang kemudian akan dilaksanakan akad jual-beli antara ba'i dengan musytari dalam akad murabahah, meskipun secara langsung bukti kepemilikan barang dari pihak pemilik mobil langsung diserahkan kepada musytari dan kepemilikan langsung berpindah dari pemilik (supplier) ke musytari, secara teori dan pelaksanaannya, skema kedua inilah yang sesuai dengan Fatwa Dewan Syariah Nasional yang dijadikan dasar hukum akad murabahah dalam perbankan syariah;

c. Contoh akad pembiayaan murabahah untuk pembelian sebuah rumah (pembiayaan KPR oleh bank syariah sebagai contoh BTPN Syariah), yaitu sebagai berikut: untuk kepentingan musytari pihak bank (ba'i) terlebih dahulu membeli rumah (yang dibutuhkan musytari) dari penjual atau developer untuk kemudian menjual kembali kepada musytari sebesar harga beli dari developer ditambah sejumlah keuntungan yang dimintakan oleh bank dan disetujui atau disepakati oleh musytari;

d. Contoh akad murabahah untuk persediaan modal kerja (modal kerja barang) seperti peralatan pabrik, sama seperti akad pembiayaan murabahah pengadaan barang lain pada umumnya, yaitu bank (ba'i) membelikan terlebih dahulu barang tersebut dari supplier kemudian ba'i menjual barang tersebut pada musytari melalui akad murabahah denganharga sebesar harga pokok ditambah keuntungan yang telah disepakati antara ba'i dan musytari;

Berdasarkan hal-hal tersebut di atas, peran bank selaku ba'i dalam pembiayaan murabahah lebih tepat digambarkan sebagai pembiaya dan bukan penjual barang, karena bank tidak memegang barang, tidak pula mengambil risiko atasnya. Kerja bank (ba'i) hampir semuanya hanya terkait dengan penanganan dokumen-dokumen. Kontrak murabahah umumnya ditanda-tangani sebelum ba'i mendapatkan barang yang dipesan oleh musytari, dalam kontrak tersebut musytari lah yang harus berhatihati dan mematuhi hukum dan aturan yang terkait dengan pengiriman barang, rasio laba, dan spesifikasi yang benar. Musytari sendirilah yang menanggung semua tanggung jawab atas denda atau 
sanksi hukum yang diakibatkan dari pelanggaran hukum tersebut. Ba'i tidak berkeinginan memikul tanggung jawab yang terkait dengan barang, karena itu segala risiko yang terkait dengannya yang secara teoritis harus ditanggung ba'i, secara efektif telah terhindarkan. Musytari menyelesaikan kerugian tersebut bukan dengan ba'i akan tetapi dengan pihak supplier.

\section{KESIMPULAN DAN SARAN}

\section{Kesimpulan}

Bank syariah di Indonesia terutama bank BTPN syariah Palangka Raya pada umumnya dalam memberikan pembiayaan murabahah, menetapkan syarat-syarat yang dibutuhkan dan prosedur yang harus ditempuh oleh musytari yang hampir sama dengan syarat dan prosedur kredit sebagaimana lazimnya yang ditetapkan oleh bank konvensional. Syarat dan ketentuan umum pembiayaan murabahah, yaitu: Umum, tidak hanya diperuntukkan untuk kaum muslim saja; Harus cakap hukum, sesuai dengan KUH Perdata; Memenuhi 5 C yaitu: Character (watak); Collateral (jaminan); Capital (modal); Condition of economy (prospek usaha); Capability (kemampuan).

Memenuhi ketentuan Bank Indonesia dan pemerintah, sesuai yang diatur dalam Undang-Undang No. 10 Tahun 1998 tentang Perubahan Undang-Undang No. 7 Tahun 1992 tentang Perbankan; Jaminan (dhomman), biasanya cukup dengan barang yang dijadikan obyek perjanjian namun karena besarnya pembiayaan lebih besar dari harga pokok barang (karena ada mark up) maka pihak bank mengenakan uang muka senilai kelebihan jumlah pembiayaan yang tidak tertutup oleh harga pokok barang.

Hambatan yang sering muncul adalah adanya cidera janji. Cidera janji yang dilakukan oleh nasabah pada Bank BTPN Syariah Palangka Raya terbilang kecil, cidera janji itu berupa keterlambatan pembayaran yang tidak sesuai dengan waktu yang telah disepakati, dalam hal keterlambatan pembayaran nasabah dapat dibedakan menjadi dua, yaitu nasabah yang terlambat atau tidak memenuhi kewajibannya karena kondisi di luar kehendak nasabah (force majure) dan nasabah yang mampu namun menunda-nunda pembayaran. 


\section{Saran}

Minimnya pengetahuan masyarakat terkait Pembiayaan pembelian dengan prinsip jual beli syariah termasuk di dalamnya pembiayaan Murabahah. Jika dibandingkan dengan bank Konvensional, maka sangat dibutuhkan program sosialisasi yang intens bagi masyarakat Palangka Raya khususnya dan Indonesia pada umumnya yang memiliki jumlah penduduk muslim yang sangat besar. Hal ini dapat dilakukan salah satunya dengan kerjasama antara para pihak terkait, misalnya bank dengan instansi pemerintah.

Dalam segala aktivitasnya baik bank maupun nasabah diharapkan tetap menjaga prinsip-prinsip syariah dalam menjalankan usahanya, karena disadari atau tidak hal itu menjadi wahana membiasakan penerapan prinsip-prinsip syariah dalam bermuamalah bagi umat Islam dalam kehidupan bermasyarakat sebagai bagian dari segala aktivitas kehidupan sehari-hari.

\section{REFERENSI}

Antonio, Muhammad Syafi'i. 2001. Bank Syariah: Dari Teori ke Praktik. Jakarta: Gema Insani Press.

Dudi, J., \& Bramantyo, R. Y. 2019. Keluarga Sebagai Basis Kerukunan Umat Beragama Di Sei Gohong, Palangka Raya Kalimantan Tengah. Mediasosian, Vol. 3(2).

Fatwa Dewan Syariah Nasional No: 04/DSN-MUI/IV/2000 tentang Murabahah.

Fatwa Dewan Syariah Nasional No: 13/DSN-MUI/IX/2000 tentang Uang Muka Dalam Murabahah

Fatwa Dewan Syariah Nasional No: No: 16/DSN-MUI/IX/2000 tentang Diskon Dalam Murabahah.

Fatwa Dewan Syariah Nasional No: 17/DSN-MUI/IX/2000 tentang Sanksi Atas Nasabah Mampu Yang Menunda-Nunda Pembayaran.

Hanum, F. (2018). Akuntabilitas Keuangan Desa (Studi Kasus Desa Ngentrong Kecamatan Karangan Kabupaten Nganjuk). Mediasosian, Vol. 2(1), hal. 51-56.

Ismail. 2011. Perbankan Syariah. Jakarta. Kencana Prenadamedia.

Karim, Adiwarman 2007. Bank Islam Analisis Fikih dan Keuangan. Jakarta: PT Raja Grafindo Persada 
Mujiarto, M., Susanto, D., \& Bramantyo, R. Y. 2019. Strategi Pelayanan Kesehatan Untuk Kepuasan Pasien Di UPT Puskesmas Pandean Kecamatan Dongko Kabupaten Trenggalek. Jurnal Mediasosian: Jurnal Ilmu Sosial Dan Administrasi Negara, 3(1). 